\title{
ECOLOGY OF AVIAN SETTLEMENTS IN LAKE TONGA (NORTHEAST ALGERIA)
}

\author{
K. Loucif ${ }^{1,2,3}$, M. Bara ${ }^{3 *}$, A. Grira ${ }^{4}$, M. C. Maazi ${ }^{2}$, A. Hamli ${ }^{3}$, M. Houhamdi ${ }^{3}$, \\ ${ }^{1}$ Department of Veterinary Sciences, University of Chadli Bendjedid, 36000 El Tarf, Algeria \\ ${ }^{2}$ Department of Biology, Faculty of Natural and Life Sciences, \\ University Mohamed Chérif Messaidia of Souk-Ahras, 41000 Souk-Ahras, Algeria \\ ${ }^{3}$ Laboratoire Biologie, Eau et Environnement (LBEE). Faculté SNV-STU, \\ Université 8 Mai 1945 Guelma. BP. 401 24000. Guelma (Algeria) \\ ${ }^{4}$ National Park of El Kala, 36100 El Kala, El Tarf, Algeria \\ E-mail: M.BARA@live.com \\ ${ }^{\star}$ Corresponding author \\ K. Loucif (https://orcid.org/0000-0002-2046-2830) \\ M. Bara (https://orcid.org/0000-0003-3818-424X)
}

Ecology of Avian Settlements in Lake Tonga (Northern Algeria). Loucif, K, Bara, M., Grira, A., Maazi, M. C., Hamli, A., Houhamdi, M. - Lake Tonga is an integral reserve within the El-Kala National Park, Biosphere Reserve and Ramsar site. This study consists in determining the diversity and phenology status of waterbirds in this reserve over an entire annual cycle (2017-2018). The census was carried out from fixed observation points. Of the 35 species recorded, wintering birds dominate with 12 species (34\%), followed by breeding sedentary species with 11 species (32\%). The breeding water bird populations are dominated by the common coot Fulica atra, (with a maximum of 6,033 birds) followed by the Anatidae, Herons and Grebes. Lake Tonga is a breeding area for several avian species and a recruitment site for a multitude species bird during the wintering period. Three Anatidae nest at Lake Tonga: The Whiteheaded duck Oxyura leucocephala, The Ferruginous duck Aythya nyroca and Mallard Anas platyrhynchos. Key words: Lake Tonga, diversity, phenology, waterbirds, breeding.

\section{Introduction}

Wetlands are the transitional link between aquatic and terrestrial ecosystems (Torell et al., 2001; Zedler, Kercher, 2005) and are very important for biodiversity conservation and management (Farinha, Trindade, 1994). In addition to providing important ecosystem services (Bassi et al., 2014), wetlands support a wide range of wildlife (Buckton, 2007). The composition of these species and the interactions between them, as well as abiotic factors, are the fundamental elements of these environments (Groombridge, Jenkins, 2002). Biodiversity should be monitored and protected because losses at this scale can be irreversible (Chapin et al., 2000; Brooks et al., 2006). Waterbirds are an important component of wetlands because they can occupy multiple trophic 
levels and play a role in the nutrient cycles of these areas (Rajashekara, Venkatesha, 2010; Sharma, Saini, 2014). Because of their high mobility, birds respond quickly to changes in the quality and condition of their habitat (Morrison, 1986) and are therefore frequently used as bio indicators of ecological health and human disturbance (Custer, Osborn, 1977; Subramanya, 1996). Wild birds are therefore a good bio indicator for several reasons: They are relatively easy to identify, the ecology of bird species is well documented and they play an important role in the sustainable development process. Moreover, the spatial distribution of these birds in wetlands is influenced by two seasons (nesting season and hunting season), and the combination of these seasons allows quantitative assessment of this local avifauna (Chernichko et al., 2018).

Inventorying is the most common approach to studying species richness (Hill et al., 2005). Natural resource inventory is an important tool used by many biologists and ecologists to infer information on the relationships between habitats, species diversity and abundance, and the effects of environmental management and change on populations over a given period (Bensaci et al., 2013). Thus, through bird inventory, future management and conservation strategies can be better guided.

Our objective is to determine the diversity of bird species, their richness, monitor their group size evolution throughout an annual cycle in order to determine their phenology status in the most important region of Algeria, Lake Tonga Nature Reserve (El-Kala National Park) also considered a Biosphere Reserve and Ramsar site since 1983. This site remains very vulnerable to the disturbances effects caused by human activities (intense poaching all year round, egg looting...etc.). Thus, an estimate of all waterfowl species population in the Lake Tonga Nature Reserve was carried out with monitoring of the diversity and abundance of numbers.

\section{Material and methods}

Lake Tonga $\left(36^{\circ} 52^{\prime} \mathrm{N}, 8^{\circ} 30^{\prime} \mathrm{E}\right)$ is a shallow $(1.5$ to $2.5 \mathrm{~m})$ freshwater wetland with a total area of about 2400 hectares. It is located in the extreme northeast of Algeria (fig. 1, Annex 2). It is included in the El-Kala National Park and exhibits a Ramsar site since 1983 and important area for bird conservation 'IBA' (Fishpool, Evans, 2001). The richness of the aquatic avifauna of this wetland is largely determined by the diversity of habitats distributed in mosaics over the entire site and its associated periphery (Boumezbeur, 1993; Kadid et al., 2007; Bakaria et al., 2009; Benyacoub et al., 2011) where include a high diversity of plant species and vegetation groups. Two main categories of plants can be distinguished: helophytes represented mainly by Scirpus lacustris, Iris pseudoacorus, Sparganium erectum, Phragmites australis and Typha angustifolia and hydrophytes represented by Nymphaea alba, Potamogeton lucens, Myriophyllum alterniflorum (Kadid et al., 2007). Within the water body, there are two large trees: Alnus glutinosa and Taxodium distichum (Kadid et al., 2007).

The study and monitoring of the Lake Tonga Waterbirds population phenology was carried out from September 2017 to August 2018 using a KonuSpot-100 20-60 x 100 ornithological telescope. Nine fixed observation sites were selected. The spatial distribution of the sampling sites was based on their unobstructed view and in such a way as to cover the entire site (Annex 1). The count was done twice a month but for each month, only one of the two counts was taken into consideration (one with the highest bird's number for each

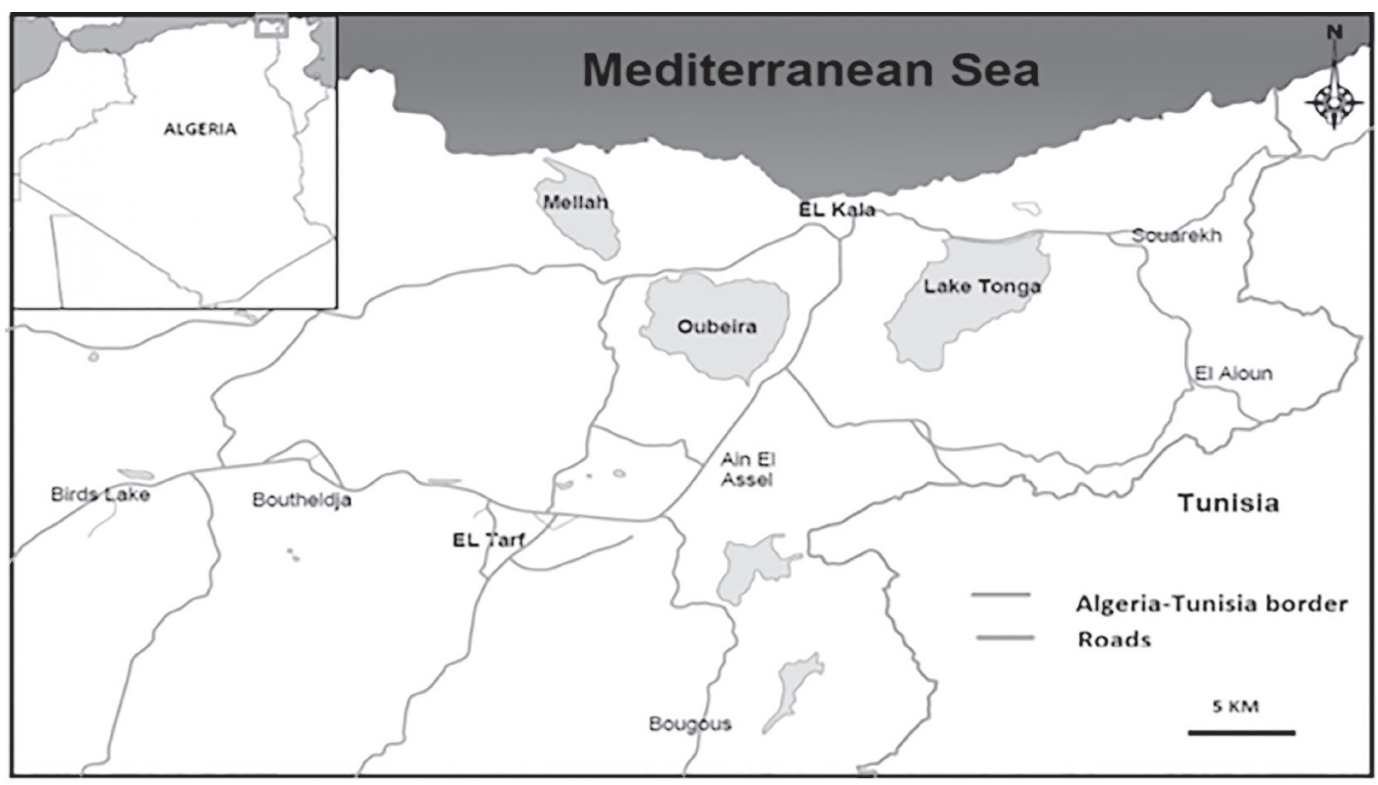

Fig. 1. Geographical location of wetlands in northeast of Algeria. 
species). The count was conducted in two ways: either an individual count if the group has a small number of individuals not exceeding 200 and is located at a close distance (less than 200 metres), and a visual estimate if the group is remote and/or stand size is large enough. In this case, the visual field is divided into several bands; the number of birds in an average band is counted and reported as many times as bands (Lamotte, Bourrelière, 1969; Blondel, 1975; Legendre, Legendre, 1979; Tamisier, Dehorter, 1999; Elphick, 2008). This method is the most commonly used in waterbird censuses (Aissaoui et al., 2011; Houhamdi, Samraoui, 2001, 2002, 2003, 2008; Seddik et al., 2010; Metallaoui et al., 2009; Bensaci et al., 2011; Amor Abda et al., 2015; Merzoug et al., 2015). The margin of error in this method is often estimated among professionals at between 05 and $10 \%$ (Houhamdi, 2002; Boukrouma et al., 2011). Calculations of the species richness, overall abundance, Shannon's diversity index $\left(\mathrm{H}^{\prime}\right)$ and equitability index were carried out in order to estimate the equilibrium of the bird populations in this Lake (Houhamdi, Samraoui, 2002, Metallaoui, Houhamdi, 2008, 2010; Maazi et al., 2010; Merzoug et al., 2014).

\section{Results and discussion}

During our follow-up, thirty-five species of waterbirds have visited this water body (Annex 3). The largest abundance and the majority of species were observed during the wintering season. The site is also an important nesting area for many bird species (fig. 2, Annex 4). In terms of populations size the common coot Fulica atra, far outweighs all the recorded bird populations. By its gregarious behaviour and easily observable, it is the most abundant species in this wetland with a maximum of 6033 birds recorded during the winter season (Annex 3).

In general terms, on the 35 species of aquatic birds recorded in Lake Tonga, winterers dominate with twelve species. Eleven species are sedentary nesting; five are summer nesting three are non-nesting sedentary and three are in transit. Only one species is considered as a non-nesting summering species (fig. 2).

The wintering season generally extends from September to March. It is characterized by the observation of the largest bird populations. Several species of waterbirds wintering further south in the High Plateaus and Sahara (Houhamdi, Samraoui, 2002; Saheb et al., 2009; Maazi et al., 2010; Baaziz et al., 2011; Seddik et al., 2012) use Lake Tonga as a temporary resting site and therefore they exhibit a phenology status as a passing species (Annex 3). Other seabirds, especially the Laridae, come to desalinate their wings in this fresh water lake.

The nesting period extends on average from April to June. In general, seventeen species are considered as regular nesters in this water body (Annex 3). The Anatidae, Rallidae, Ardeidae and Podicipedidae mainly represent them. Anatidae are represented by three species, two of which are on the IUCN Red List. These are the mallard Anas platyrhynchos, the white-headed duck Oxyura leucocephala and the ferruginous duck Aythya nyroca (Loucif et al., 2018). All Rallidae species observed at this site have a nesting status. The

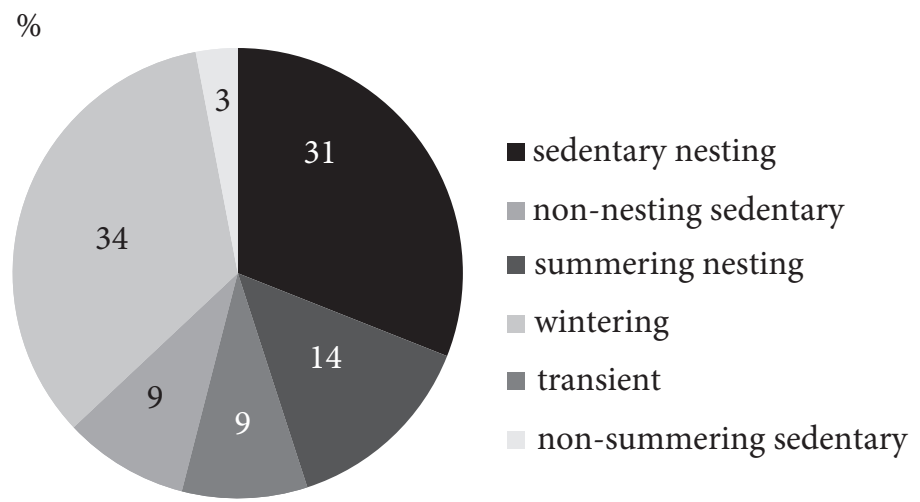

Fig. 2. Status of avian species in Lake Tonga. 


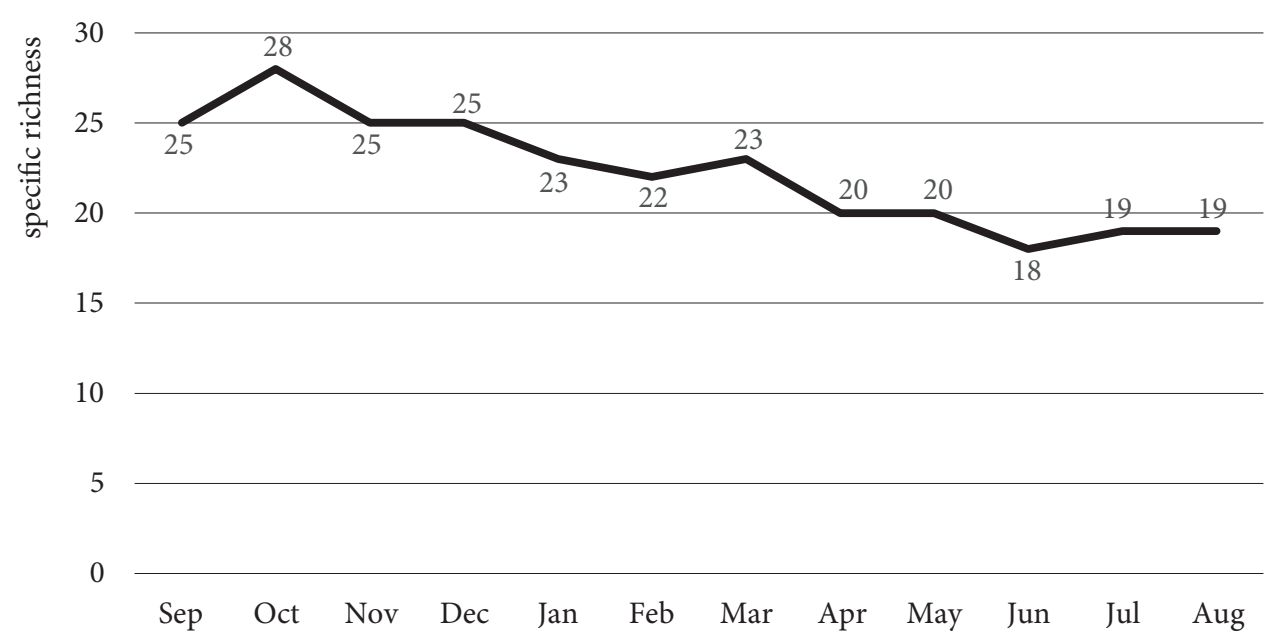

Fig. 3. Evolution of the specific richness of waterbirds at Lake Tonga.

common coot is by far the most abundant. The purple swamphen Porphyrio porphyrio is also included in the IUCN Red List and therefore we can say that Lake Tonga is a very important site for waterbirds in our country (Boumezbeur, 1993; Benyacoub et al., 2011). It should be noted that Lake Tonga is the only nesting site of the Whiskered Tern Chlidonias hybrida in Algeria and North Africa (Bakaria et al., 2009).

In terms of species richness, 35 waterbirds species belonging to 13 families were recorded from Tonga Lake. The highest species richness value is recorded in October with 28 species. During this period, also the summer, winter and transient species are encountered, with the passage of 15 individuals of greater flamingo Phoenicopterus roseus and the arrival of three couples of common shelduck Tadorna tadorna These two species have increased the ornithological richness to 28 . The minimum value is recorded during the summer period and mainly during June with 18 species. The specific richness graph also shows us that a high number of waterbirds characterizes the wintering period (fig. 3 ).

The aspect of the graph of the total waterbirds abundance also shows us that during the wintering period, a large aquatic bird population frequents Lake Tonga. The highest numbers were recorded at the beginning of the wintering season during December and January with respectively (7899 birds as the maximum observed during this study) and 6963 birds in January. This period corresponds to the passage of wintering migratory waterbirds further south (Houhamdi, 2002; Saheb et al., 2009; Seddik et al., 2012; Dziri et

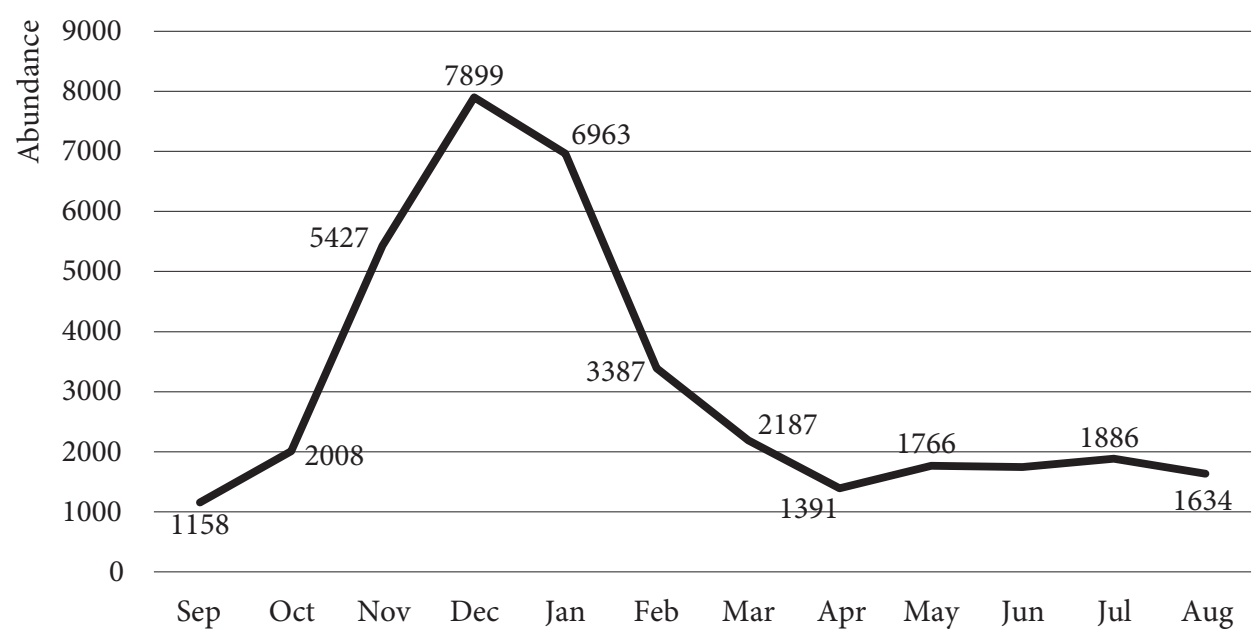

Fig. 4. Evolution of the total abundance of waterbirds in Lake Tonga. 


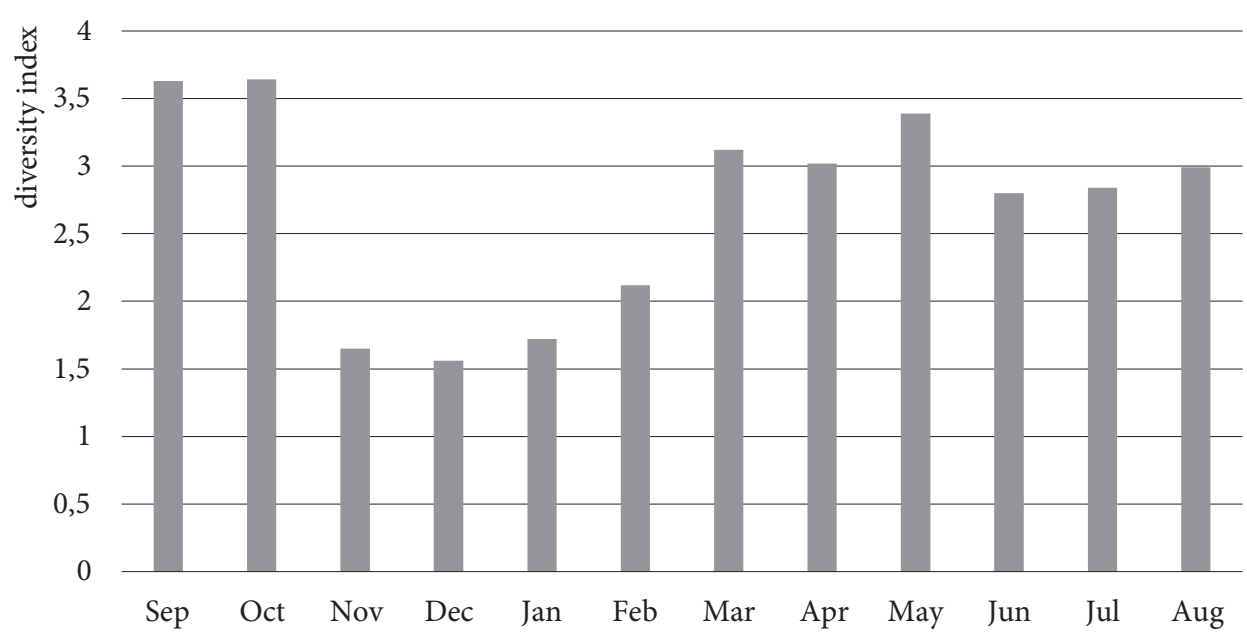

Fig. 5. Evolution of the diversity index at Lake Tonga.

al., 2014; Elafri et al., 2016; Halassi et al., 2016). The lowest number was recorded in the spring, during April, with 1391 waterbirds. Beyond January until the end of wintering, waterbird numbers have decreased (fig. 4).

The Shannon and Weaver Diversity Index (H'), which measures the degree of complexity of a settlement, the higher it is, the more it corresponds to a settlement composed of a large number of species with a low representation (Houhamdi, 2002). Conversely, a low value reflects a settlement dominated by a species or a settlement with a small number of species with a high degree of representativeness (Blondel, 1995; Olsson et al., 2004). During the months of November, December and January, the diversity index is low, at 1.65, 1.56 and 1.72 respectively, reflecting a poorly diversified and unbalanced population, since some species in terms of abundance largely dominate the population during this period, such as the common coot and common teal Anas crecca. September and October are the most diversified months. They have high values and rates of this index, or 3.63 and 3.64; consequently, they display the perfect balance throughout the study period (fig. 5).

The graph of the equitability index explains better the equilibrium of the populations; it tends towards zero, when a species largely dominates the population and is equal to one when all species have the same abundance. The evolution of this graph presents us with a maximum value noted during September and May $(\mathrm{E}=0.78)$. This means that there is an equilibrium between the numbers of species during these periods. During November,

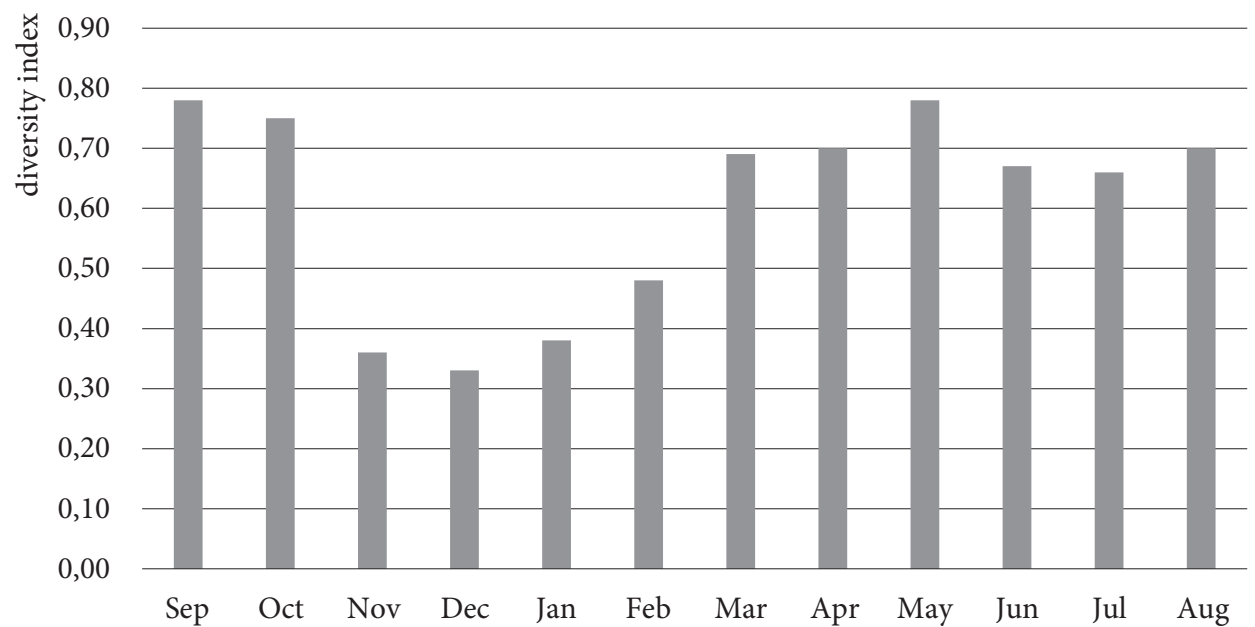

Fig. 6. Evolution of the equitability Index at Lake Tonga. 
December and January, equity is as low as Shannon's diversity $(0.36,0.33$, and 0.38$)$ reflecting a poorly diversified and unbalanced stand, because some species largely dominate the bird population in terms of abundance, in particular the common coot (fig. 6).

\section{Conclusion}

The avian diversity in Lake Tonga is high; it mainly determined by the diversity of habitats distributed over the entire surface area. This nature reserve is an excellent nesting site for several bird species and a major source of recruitment for a multitude waterfowl species especially during the wintering period. This period extends from September to March with a preferential period from November to January during which the maximum numbers are reached for most species. It is a period of transit and passage for waterbirds to wintering sites further south. This wetland also provides a suitable breeding ground for waterbirds, where seventeen nest in this lake. Some are internationally very important, as White-headed Duck, Ferruginous Duck and Purple Swamphen. However, this site remains very vulnerable to the disturbances effects caused by human activities; whether they are authorized or prohibited (fishing, poaching throughout the year, eggs collection). It is also important to note that the increasing use of the surrounding areas by visitors and hikers is a major source of disturbance for wildlife. It is therefore essential to ensure that any direct or indirect degradation is prevented and to ensure that the very attractive wilderness character of this reserve is maintained.

Annex 1. Specific geocoding information of sampling sites

\begin{tabular}{cc}
\hline Sampling sites & Specific geocoding information \\
\hline S1 & $36^{\circ} 52^{\prime} 47.8^{\prime \prime} \mathrm{N} 8^{\circ} 31^{\prime} 48.9^{\prime \prime} \mathrm{E}$ \\
S2 & $36^{\circ} 52^{\prime} 25.1^{\prime \prime} \mathrm{N} 8^{\circ} 31^{\prime} 58.7^{\prime \prime} \mathrm{E}$ \\
S3 & $36^{\circ} 51^{\prime} 15.4^{\prime \prime} \mathrm{N} 8^{\circ} 31^{\prime} 51.7^{\prime \prime} \mathrm{E}$ \\
S4 & $36^{\circ} 50^{\prime} 43.0^{\prime \prime} \mathrm{N} 8^{\circ} 31^{\prime} 29.7^{\prime \prime} \mathrm{E}$ \\
S5 & $36^{\circ} 49^{\prime} 39.5^{\prime \prime} \mathrm{N} 8^{\circ} 28^{\prime} 34.4^{\prime \prime} \mathrm{E}$ \\
S6 & $36^{\circ} 50^{\prime} 23.0^{\prime \prime} \mathrm{N} 8^{\circ} 27^{\prime} 56.5^{\prime \prime} \mathrm{E}$ \\
S7 & $36^{\circ} 50^{\prime} 55.3^{\prime \prime} \mathrm{N} 8^{\circ} 28^{\prime} 03.0^{\prime \prime} \mathrm{E}$ \\
S8 & $36^{\circ} 51^{\prime} 38.6^{\prime \prime} \mathrm{N} 8^{\circ} 28^{\prime} 32.8^{\prime \prime} \mathrm{E}$ \\
S9 & $36^{\circ} 52^{\prime} 20.3^{\prime \prime} \mathrm{N} 8^{\circ} 29^{\prime} 23.8^{\prime \prime} \mathrm{E}$ \\
\hline
\end{tabular}
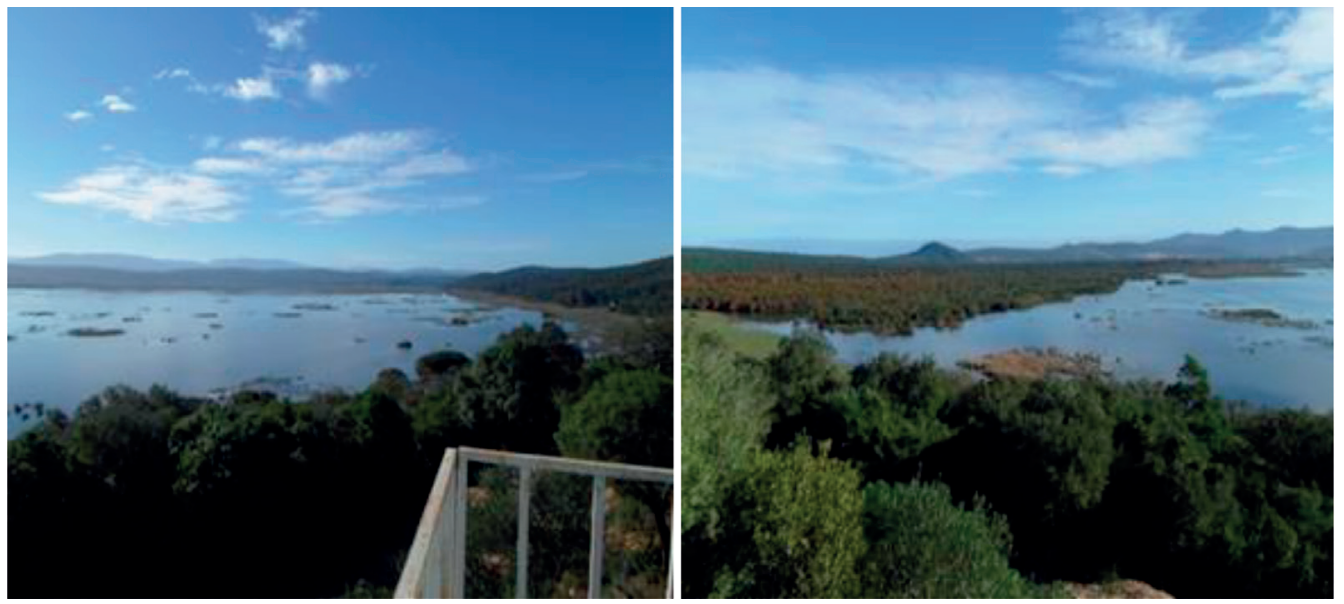

Annex 2. General view of Lake Tonga (Loucif shot on November 2017). 
Annex 3. Phenological status of waterbirds at Lake Tonga

\begin{tabular}{|c|c|c|c|c|c|}
\hline Family & Common Name & Scientific Name & Min & $\operatorname{Max}$ & $\begin{array}{c}\text { Phenological } \\
\text { status }\end{array}$ \\
\hline 1 & 2 & 3 & 4 & 5 & 6 \\
\hline \multirow[t]{10}{*}{ Anatidae } & Common Teal & $\begin{array}{c}\text { Anas crecca } \\
\text { (Linnaeus, 1758) }\end{array}$ & 38 & 603 & Wintering \\
\hline & Gadwall & $\begin{array}{l}\text { Mareca strepera } \\
\text { (Linnaeus, 1758) }\end{array}$ & 22 & 350 & Late Winterer \\
\hline & $\begin{array}{l}\text { Northern } \\
\text { Shoveler }\end{array}$ & $\begin{array}{l}\text { Spatula clypeata } \\
\text { (Linnaeus, 1758) }\end{array}$ & 11 & 624 & Wintering \\
\hline & $\begin{array}{l}\text { Eurasian Wi- } \\
\text { geon }\end{array}$ & $\begin{array}{l}\text { Mareca penelope } \\
\text { (Linnaeus, 1758) }\end{array}$ & 38 & 426 & Wintering \\
\hline & Mallard & $\begin{array}{l}\text { Anas platyrhynchos } \\
\text { Linnaeus, } 1758\end{array}$ & 2 & 35 & $\begin{array}{l}\text { Sedentary } \\
\text { nesting }\end{array}$ \\
\hline & Garganey & $\begin{array}{l}\text { Spatula querquedula } \\
\text { (Linnaeus, 1758) }\end{array}$ & 14 & 14 & Transient \\
\hline & $\begin{array}{l}\text { White-headed } \\
\text { Duck }\end{array}$ & $\begin{array}{l}\text { Oxyura leucocephala } \\
\text { (Scopoli, 1769) }\end{array}$ & 4 & 24 & $\begin{array}{l}\text { Sedentary } \\
\text { nesting }\end{array}$ \\
\hline & $\begin{array}{l}\text { Common Po- } \\
\text { chard }\end{array}$ & $\begin{array}{c}\text { Aythya ferina } \\
\text { (Linnaeus, 1758) }\end{array}$ & 3 & 42 & Wintering \\
\hline & $\begin{array}{l}\text { Ferruginous } \\
\text { Duck }\end{array}$ & $\begin{array}{c}\text { Aythya nyroca } \\
\text { (Güldenstädt, 1770) }\end{array}$ & 6 & 236 & $\begin{array}{l}\text { Sedentary } \\
\text { nesting }\end{array}$ \\
\hline & $\begin{array}{l}\text { Common Shel- } \\
\text { duck }\end{array}$ & $\begin{array}{l}\text { Tadorna tadorna } \\
\text { (Linnaeus, 1758) }\end{array}$ & 6 & 6 & Transient \\
\hline \multirow[t]{3}{*}{ Rallidae } & $\begin{array}{l}\text { Common } \\
\text { Moorhen }\end{array}$ & $\begin{array}{l}\text { Gallinula chloropus } \\
\text { (Linnaeus, 1758) }\end{array}$ & 2 & 85 & $\begin{array}{l}\text { Sedentary } \\
\text { nesting }\end{array}$ \\
\hline & Common Coot & $\begin{array}{c}\text { Fulica atra } \\
\text { (Linnaeus, 1758) }\end{array}$ & 245 & 6033 & $\begin{array}{l}\text { Sedentary } \\
\text { nesting }\end{array}$ \\
\hline & $\begin{array}{c}\text { Purple } \\
\text { Swamphen }\end{array}$ & $\begin{array}{l}\text { Porphyrio porphyrio } \\
\text { (Linnaeus, 1758) }\end{array}$ & 2 & 24 & $\begin{array}{c}\text { Sedentary } \\
\text { nesting }\end{array}$ \\
\hline \multirow[t]{7}{*}{ Ardeidae } & Squacco Heron & $\begin{array}{c}\text { Ardeola ralloides } \\
\text { (Scopoli, 1769) }\end{array}$ & 7 & 138 & $\begin{array}{l}\text { Summering } \\
\text { Nesting }\end{array}$ \\
\hline & Little Egret & $\begin{array}{l}\text { Egretta garzetta } \\
\text { (Linnaeus, 1766) }\end{array}$ & 19 & 140 & $\begin{array}{l}\text { Sedentary } \\
\text { nesting }\end{array}$ \\
\hline & Grey Heron & $\begin{array}{c}\text { Ardea cinerea } \\
\text { (Linnaeus, 1758) }\end{array}$ & 1 & 39 & $\begin{array}{l}\text { Non-nesting } \\
\text { Sedentary }\end{array}$ \\
\hline & Cattle Egret & $\begin{array}{c}\text { Bubulcus ibis } \\
\text { (Linnaeus, 1758) }\end{array}$ & 2 & 506 & $\begin{array}{l}\text { Sedentary } \\
\text { nesting }\end{array}$ \\
\hline & Purple Heron & $\begin{array}{l}\text { Ardea purpurea } \\
\text { ( Linnaeus, 1766) }\end{array}$ & 2 & 50 & $\begin{array}{l}\text { Summering } \\
\text { Nesting }\end{array}$ \\
\hline & $\begin{array}{l}\text { Great White } \\
\text { Egret }\end{array}$ & $\begin{array}{c}\text { Ardea alba } \\
\text { (Linnaeus, 1758) }\end{array}$ & 1 & 55 & Wintering \\
\hline & $\begin{array}{l}\text { Black-Crowned } \\
\text { Night Heron }\end{array}$ & $\begin{array}{c}\text { Nycticorax nycticorax } \\
\text { (Linnaeus, 1758) }\end{array}$ & 24 & 39 & $\begin{array}{l}\text { Summering } \\
\text { Nesting }\end{array}$ \\
\hline Phalacrocoracidae & $\begin{array}{c}\text { Great } \\
\text { Cormorant }\end{array}$ & $\begin{array}{l}\text { Phalacrocorax carbo } \\
\text { (Linnaeus, 1758) }\end{array}$ & 7 & 155 & $\begin{array}{l}\text { Non-nesting } \\
\text { Sedentary }\end{array}$ \\
\hline \multirow[t]{2}{*}{ Podicipedidae } & $\begin{array}{l}\text { Little } \\
\text { Grebe }\end{array}$ & $\begin{array}{c}\text { Tachybaptus ruficollis ( } \\
\text { Pallas, 1764) }\end{array}$ & 1 & 122 & $\begin{array}{l}\text { Sedentary } \\
\text { nesting }\end{array}$ \\
\hline & $\begin{array}{c}\text { Great Crested } \\
\text { Grebe }\end{array}$ & $\begin{array}{l}\text { Podiceps cristatus } \\
\text { (Linnaeus, 1758) }\end{array}$ & 2 & 44 & $\begin{array}{c}\text { Sedentary } \\
\text { nesting }\end{array}$ \\
\hline \multirow[t]{2}{*}{ Threskiornithidae } & $\begin{array}{l}\text { Glossy } \\
\text { Ibis }\end{array}$ & $\begin{array}{l}\text { Plegadis falcinellus } \\
\text { (Linnaeus, 1766) }\end{array}$ & 7 & 312 & $\begin{array}{l}\text { Summering } \\
\text { Nesting }\end{array}$ \\
\hline & $\begin{array}{l}\text { Eurasian } \\
\text { Spoonbill }\end{array}$ & $\begin{array}{l}\text { Platalea leucorodia } \\
\text { (Linnaeus, } 1758\end{array}$ & 8 & 160 & Wintering \\
\hline Accipitridae & $\begin{array}{c}\text { Western } \\
\text { Marsh-harrier }\end{array}$ & $\begin{array}{l}\text { Circus aeruginosus } \\
\text { (Linnaeus, 1758) }\end{array}$ & 1 & 12 & $\begin{array}{l}\text { Sedentary } \\
\text { nesting }\end{array}$ \\
\hline Pandionidae & Osprey & $\begin{array}{l}\text { Pandion haliaetus } \\
\text { (Linnaeus, 1758) }\end{array}$ & 1 & 7 & Wintering \\
\hline
\end{tabular}


Continied Annex 3.

\begin{tabular}{|c|c|c|c|c|c|}
\hline 1 & 2 & 3 & 4 & 5 & 6 \\
\hline Phoenicopteridae & $\begin{array}{l}\text { Greater Fla- } \\
\text { mingo }\end{array}$ & $\begin{array}{c}\text { Phoenicopterus roseus } \\
\text { (Pallas, 1811) }\end{array}$ & 15 & 15 & Transient \\
\hline Recurvirostridae & $\begin{array}{l}\text { Black-winged } \\
\text { Stilt }\end{array}$ & $\begin{array}{l}\text { Himantopus himantopus } \\
\text { (Linnaeus, 1758) }\end{array}$ & 6 & 160 & Wintering \\
\hline Charadriidae & $\begin{array}{l}\text { Northern } \\
\text { Lapwing }\end{array}$ & $\begin{array}{l}\text { Vanellus vanellus ( } \\
\text { Linnaeus, 1758) }\end{array}$ & 6 & 300 & Wintering \\
\hline \multirow[t]{2}{*}{ Scolopacidae } & Common Snipe & $\begin{array}{l}\text { Gallinago gallinago } \\
\text { (Linnaeus, 1758) }\end{array}$ & 1 & 7 & Wintering \\
\hline & $\begin{array}{l}\text { Common } \\
\text { Sandpiper }\end{array}$ & $\begin{array}{l}\text { Actitis hypoleucos } \\
\text { (Linnaeus, 1758) }\end{array}$ & 1 & 11 & Wintering \\
\hline \multirow[t]{3}{*}{ Laridae } & $\begin{array}{l}\text { Black-headed } \\
\text { Gull }\end{array}$ & $\begin{array}{l}\text { Larus ridibundus } \\
\text { (Linnaeus, 1766) }\end{array}$ & 2 & 95 & $\begin{array}{l}\text { Non-nesting } \\
\text { Summering }\end{array}$ \\
\hline & $\begin{array}{l}\text { Yellow-legged } \\
\text { Gull }\end{array}$ & $\begin{array}{l}\text { Larus michahellis } \\
\text { J. F. Naumann, } 1840\end{array}$ & 1 & 80 & $\begin{array}{c}\text { Non-nesting } \\
\text { Sedentary }\end{array}$ \\
\hline & $\begin{array}{l}\text { Whiskered } \\
\text { Tern }\end{array}$ & $\begin{array}{l}\text { Chlidonias hybrida } \\
\quad \text { (Pallas, 1811) }\end{array}$ & 73 & 745 & $\begin{array}{l}\text { Summering } \\
\text { Nesting }\end{array}$ \\
\hline
\end{tabular}
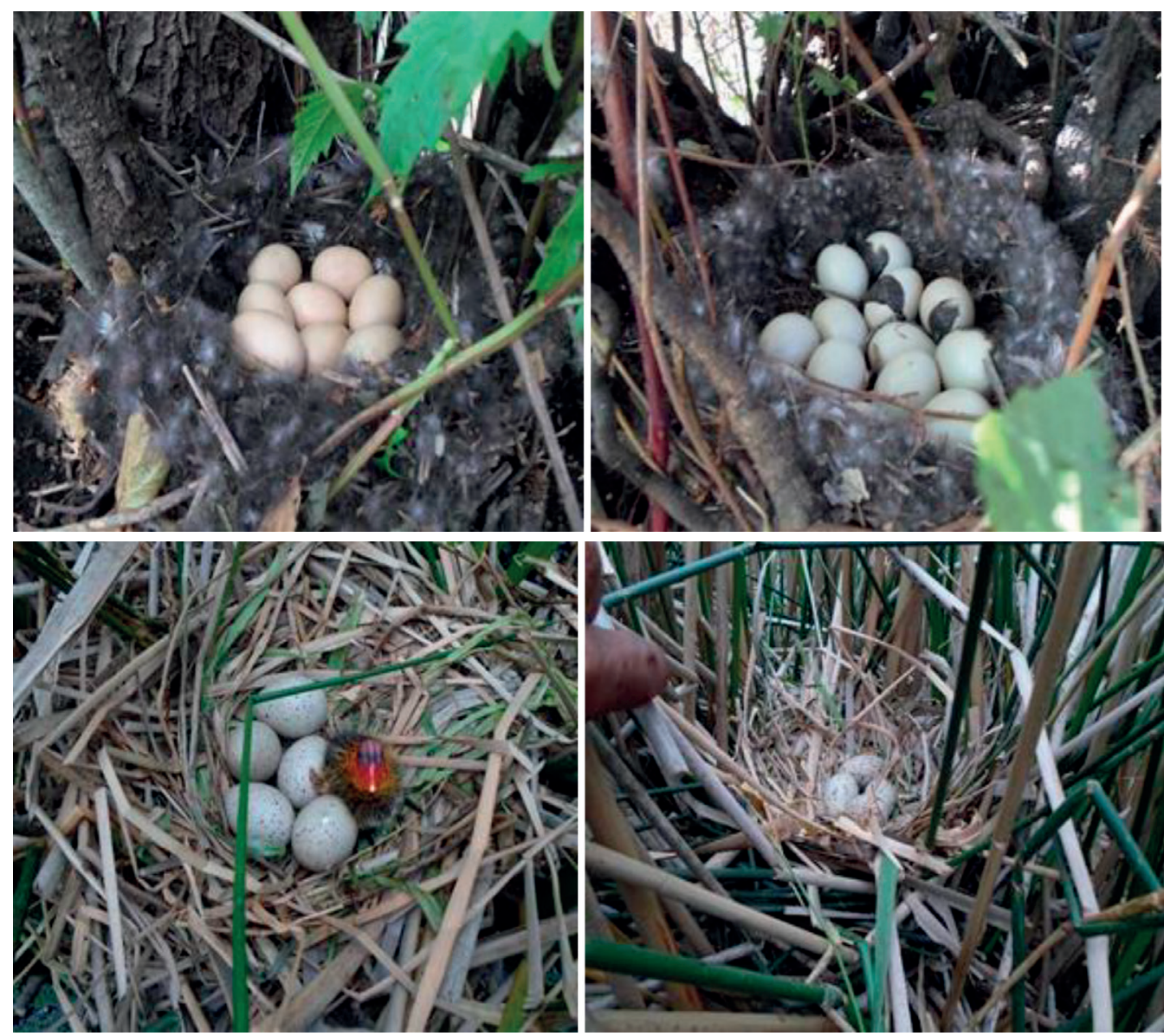

A nnex 4. Nest of Ferruginous Duck built on alder carr in Lake Tonga (top left). Nest of Mallard built on alder carr in Lake Tonga (top right). Nest of Common Coot with one chick in Lake Tonga (bottom left). Nest of Purple Swamphen in Lake Tonga (bottom right) (Loucif shot on November 2017). 
This study was supported by Direction general for scientific research and technological development (DGRSDT, Algeria) and Algerian ministry of high education and scientific research (MESRS, Algeria). Authors of this study are very grateful to these two institutions. Also, we are very grateful to reviewers for their remarks.

\section{References}

Aissaoui, R. Taher, A. Saheb, M. Gurgrueb, L., Houhamdi, M. 2011. Diurnal behaviour of Ferruginous Duck Aythya nyroca wintering at the El-Kala wetlands (Northeast Algeria). Bulletin de l'Institut Scientifique du Rabat, 33 (2), 67-75.

Amor Abda, W., Merzoug, S., Belhamra, M., Houhamdi, M. 2015. Phenology and diurnal behaviour of the Northern Shoveler Anas clypeata in the Guerbes-Sanhadja wetland complex (Northeastern Algeria). Zoology and Ecology, 25 (1), 19-25.

Baaziz, N., Mayache, B., Saheb, M., Bensaci, E., Ounissi, M., Metallaoui, S., Houhamdi, M. 2011. Statut phénologique et reproduction des peuplements d'oiseaux d'eau dans l'éco-complexe de zones humides de Sétif (Hauts plateaux, Est de l'Algérie). Bulletin de l'Institut Scientifique de Rabat, 32 (2), 77-87.

Bakaria, F., Benyacoub, S., Gauthier-Clerc, M., Bańbura, J. 2009. Long-term changes in the size, structure and location of whiskered tern Chlidoniashybrida (L.) nests in deteriorating environmental conditions of a North African lake. Polish Journal of Ecology, 57 (4), 749-759.

Bassi, N., Kumar, M. D., Sharma, A., Pardha-Saradhi, P. 2014. Status of wetlands in India: A review of extent, ecosystem benefits, threats and management strategies. Journal of Hydrology: Regional Studies 2, 1-19.

Bensaci, E., Bouzegag, A., Guergueb, E., Bounab, C., Brahmia, H., Nouidjem, Y., Zeraoula, A., Bouaguel, L., Saheb, M., Metallaoui, S., Mayache, B., Bouslama, Z., Houhamdi, M. 2011. Chott Merouane (Algérie) un nouveau site de reproduction du Flamant rose Phonicopterus roseus. Flamingo, 18, 40-47.

Bensaci, E., Saheb, M., Nouidjem, Y., Bouzegag, A., Houhamdi M., 2013. Biodiversité de l'avifaune aquatique des zones humides sahariennes: Cas d’Oued Righ (Algérie). Physio-Géo: Géographie, Physique et Environnement, $7,31-42$.

Benyacoub, S., Baba Hmed, R., Kara, H., Brahmia, Z. 2011., Plan Directeur de Gestion des Sites Ramsar du Parc National d'El Kala. Lac Tonga. Phase 2 évaluation et interprétation des données. T.A.D. Consultation for Ministère de l'Agriculture et du Développement Rural, Direction Générale des Forêts, Algeria.

Blondel, J. 1975. Analyse des peuplements d'oiseaux d'eau. Elément d'un diagnostic écologique. I. La méthode des échantillonnages fréquentiels progressifs (E.F.P). La Terre et la Vie, 29, 533-589.

Blondel, J. 1995. Biogéographie. Approche écologique et évolutive. Masson, 1-297.

Boukrouma, N., Maazi, M. C., Saheb, M., Metallaoui, S., Houhamdi, M. 2011. Hivernage du Canard Pilet Anas acuta sur les hauts plateaux de l'Est de l'Algérie. Alauda, 79 (4), 285-293.

Boumezbeur, A. 1993. Ecologie et biologie de reproduction de l'érismature à tête blanche (Oxyura leucocephala) et de fuligule nyroca (Aythya nyroca) sur le lac Tonga et le Lac des Oiseaux (Est-algérien). PhD thesis. Montpellier.

Brooks, T. M., Mittermeier, R. A., Da Fonseca, G. A., Gerlach, J., Hoffmann, M., Lamoreux, J. F., Rodrigues, A. S. 2006. Global biodiversity conservation priorities. Science, 313 (5783), 58-61.

Buckton, S. 2007. Managing wetlands for sustainable livelihoods at KoshiTappu. Danphe, 16 (1), 12-13.

Chapin-Iii, F. S., Zavaleta, E. S., Eviner, V. T., Naylor, R. L., Vitousek, P. M., Reynolds, H. L., Mack, M. C. 2000. Consequences of changing biodiversity. Nature, 405 (6783), 234.

Chernichko, J. I., Kostiushyn, V. A., Vinokurova, S. V. 2018. The amount and distribution of the red data book bird wetland species in the Azov-Black sea region of Ukraine according to the results of august counts 2004-2015. Vestnik Zoologii, 52 (2), 145-154.

Custer, T. W., Osborn, R. G. 1977. Wading birds as biological indicators: 1975 Colony Survey. Washington, US Fish and Wildlife Service.

Dziri, H., Rouidi, S., Ouakid, M. L., Houhamdi, M. 2014. Eco Ethology of the Duck Mallard (Anas platyrhynchos) wintering at the level of Garaet Hadj Tahar (Skikda, North-East Algeria). Advances in Environmental Biology, 8 (10), 324-333.

Elafri, A., Halassi, I., Houhamdi, M. 2016. Diversity patterns and seasonal variation of the waterbird community in Mediterranean wetlands of Northeastern Algeria. Zoology and Ecology, 26 (1), 9-14.

Elphick, C. S. 2008. How you count counts: the importance of methods research in applied ecology. Journal of Applied Ecology, 45 (5), 1313-1320.

Farinha, J. C., Trindade, A. 1994. Contribuição para o inventário e caracterização de zonas húmidasem Portugal Continental. Publ. MedWet/Inst. Cons. Natureza, Lisboa, 1-408.

Fishpool, L. D., Evans, M. I. 2001. Important Bird Areas in Africa and associated islands: Priority sites for conservation. Cambridge, UK, Birdlife International.

Groombridge, B., Jenkins, M. D. 2002. World Atlas of Biodiversity. Prepared by the UNEP World Conservation Monitoring Centre. Unversity of California Press, Berkeley.

Halassi, I., Elafri, A., Belhamra, M., Houhamdi, M. 2016. Répartition et abondance de l'Erismature à tête blanche Oxyura leucocephala dans les zones humides du Nord-Est algérien. Alauda, 84 (1), $23-32$.

Hill, D., Fasham, M., Tucker, G., Shewry, M., Shaw, P. 2005. Handbook of Biodiversity Methods: Survey, Evaluation and Monitoring. Cambridge University Press, New York, 1-573. 
Houhamdi, M., Samraoui, B. 2002. Occupation spatio-temporelle par l'avifaune aquatique du Lac des Oiseaux (Algérie). Alauda, 70, 301-310.

Houhamdi, M., Samraoui, B. 2003. Diurnal time budget of wintering Teal Anascrecca at Lac des Oiseaux, northeast Algeria. Wildfowl. 54, 51-62.

Houhamdi, M. 2002. Ecologie du peuplement avien du Lac des Oiseaux (Numidie orientale). Ph.D thesis, Université Annaba, 1-145.

Houhamdi, M., Samraoui, B. 2008. Diurnal and nocturnal behaviour of ferruginous duck Aythya nyroca at Lac des Oiseaux, northeast Algeria. Ardeola, 55, 59-69.

Houhamdi, M., Samraoui, B. 2001. Diurnal time budget of wintering Teal Anas crecca at Lac des Oiseaux, northeast Algeria. Wildfowl, 52 (52), 87-96.

Kadid, Y., Thébaud, G., Pétel, G., Abdelkrim, H. 2007. Les communautés végétales aquatiques de la classe des Potametea du lac Tonga, El-Kala, Algérie. Acta Botanica Gallica, 154 (4), 597-618.

Lamotte, J., Bourreliere, A. 1969. Problèmes d'écologie: l'échantillonnage des peuplements animaux des milieux terrestres. Masson, Paris.

Legendre, P., Legendre, L. 1979. Écologie numérique: la structure des données écologiques. Tome 2. Masson, Paris.

Loucif, K., Maazi, M. C., Houhamdi, M. 2018. Premières données sur les caractéristiques de la reproduction du Fuligule nyroca, Aythya nyroca dans la réserve du Lac Tonga (Nord-est de l'Algérie). Proceedings du 1er congrès nord-africain d'ornithologie \& 4ème colloque international d'ornithologie algérienne, LZA, Univ. Bejaia, 2018, 249.

Maazi, M. C., Saheb, M., Bouzegag, A., Seddik, S., Nouidjem, Y., Bensaci, E., Mayache, B., Chefrour, A., Houhamdi, M. 2010. Ecologie de la reproduction de l'Echasse blanche Himantopus himantopus dans la Garaet de Guellif (Hautes plaines de l'Est algérien). Bulletin de l'Institut Scientifique de Rabat, 32 (2), 101-109.

Merzoug, A., Bara, M., Houhamdi, M. 2015. Diurnal time budget of Gadwall Anas strepera in Guerbes-Sanhadja wetlands (Skikda, northeast Algeria). Zoology and Ecology, 5 (2), 101-105.

Merzoug, S., Abdellioui, S., Houhamdi, M. 2014. Etude de la qualité microbiologique de l'eau de l'Oued ElKébir (Skikda, Algérie). Arabian Journal of Earth Sciences, 1 (1), 276.

Metallaoui, S., Houhamdi, M. 2008. Données préliminaires sur l'avifaune aquatique de la Garaet Hadj-Tahar (Skikda, Nord-Est algérien). African Bird Club Bulletin, 15 (1), 71-76.

Metallaoui, S., Houhamdi, M. 2010. Biodiversité et écologie de l'avifaune aquatique hivernante dans Garaet Hadj-Tahar (Skikda, Nord-Est de l'Algérie). Hydroécologie Appliquée, 17, 1-16.

Metallaoui, S., Atoussi, S., Merzoug, A., Houhamdi, M. 2009. Hivernage de l'Erismature à tête blanche Oxyura leucocephala dans Garaet Hadj-Tahar (Skikda, Nord-Est de l'Algérie). Aves, 46 (3), 136-140.

Morrison, M. L. 1986. Bird populations as indicators of environmental change. In Current ornithology. Springer, Boston, MA. 429-451.

Olsson, P., Folke, C., Hahn, T. 2004. Social-ecological transformation for ecosystem management: the development of adaptive co-management of a wetland landscape in southern Sweden. Ecology and Society, 9 (4).

Rajashekara, S., Venkatesha, M. G. 2010. The diversity and abundance of waterbirds in lakes of Bangalore city, Karnataka, India. Biosystematica, 4 (2), 63-73.

Saheb, M., Bouzegag, A., Nouidjem, Y., Bensaci, E., Samraoui, B., Houhamdi, M. 2009. Ecologie de la reproduction de l'Avocette élégante Recurvirostra avosetta dans la Garaet de Guellif (Hautes plaines de l'Est algérien). Eur Journ Scien Reas, 25 (4), 513-525.

Seddik, S., Bouaguel, L., Bougoudjil, S., Maazi, M. C., Saheb, M., Metallaoui, S., Houhamdi, M. 2012. L'avifaune aquatique de la Garaet de Timerganine et des zones humides des Hauts Plateaux de l'Est algérien. Afri. Bird Club Bull, 19 (1), 25-32.

Seddik, S., Maazi, M. C., Hafid, H., Saheb, M., Mayache, B., Houhamdi, M. 2010. Statut et écologie des peuplements Laro-Limicoles et Echassiers dans les zones humides des hauts plateaux de l'Est de l'Algérie. Bulletin de l'Institut Scientifique de Rabat, 32 (2), 111-118

Sharma, K. K., Saini, M. 2014. Community structure and population dynamics of aquatic avifauna of Gharana Wetland (Reserve), Jammu, India. International Research Journal of Biological Sciences, 3 (2), 1-8.

Subramanya, S. 1996. Distribution, status and conservation of Indian heronries. Journal of the Bombay Natural History Society, 93 (3), 459-486.

Tamisier, A., Dehorter, O. 1999. Camargue : Canard et Foulques. Fonctionnement d'un prestigieux quartier d'hiver. Centre Ornithologique du Gard. Nimes.

Torell, M., Salamanca, A. M., Ahmed, M. 2001. Management of wetland resources in the Lower Mekong Basin: issues and future directions. Naga, The ICLARM Quarterly, 24 (3-4), 4-10.

Zedler, J. B., Kercher, S. 2005. Wetland resources: status, trends, ecosystem services, and restorability. Annu Rev Environ Resour, 30, 39-74.

Received 25 February 2020

Accepted 25 August 2020 